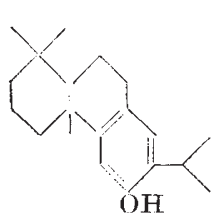

$\mathrm{OH}$

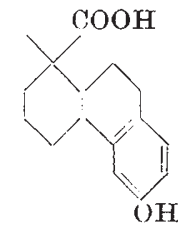

Podocarpic acid

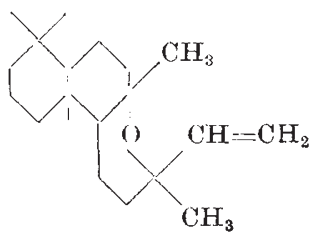

Manoyl oxide
Dacrydium, but a close relationship to, and should perhaps be placed with, Podocarpus. 'This conclusion is in agreement with the view that the anatomical features of the wood resemble those of Podocarpus (the late) C. W. Brand T

Dominion Laboratory,

Department of Scientific and Industrial Research, New Zealand.

B. R. Thomas

Birkbeck College,

London, W.C.1.

April 30.

- See Linstedt, Acta Chem. Scand., 5, 129 (1951).

2 Brandt and Thomas (unpublished).

"Brandt and Thomas, N.Z. J. Sci. Tech., R, 33, 30 (1951).

4 Brardt, N.Z. J. Sci. Tech., B, 33, 141 (1951).

- Brandt (unpublished).

- Orman and Reid, N.Z. J. For., 5, No. 3, 215 (1946).

\section{Early Effects of Growth Substances}

IsOLATED cambium-phloem strips from Bryophyllum calycinum Salisb. show a curvature with the cambium at the concave surface, and this curvature is increased when the strips are placed in water. Plasmolysis causes the complete relaxation of the strip. Partial relaxation can be obtained in solutions of indolylacetic acid and 2,4-dichlorophenoxyacetic acid $(2,4-D)$ in concentrations of 1-50 parts per million, the action of indolylacetic acid being in some cases reversible. It can be shown that the average width of the cambium cells decreases immediately after placing the strip in the hormone solution. The reaction is strongly influenced by temperature; 'it occurs between $15^{\circ}$ and $30^{\circ} \mathrm{C}$., with an optimum near $30^{\circ} \mathrm{C}$. At $29^{\circ} \mathrm{C}$. a maximal curvature of the strip (or shrinkage of the cambium cells) is obtained within five minutes. In indolylacetic acid, 1-20 p.p.m., a reversal of this shrinkage occurs which may lead to an increase beyond the original size of the cell ; this might properly be considered as growth. At $29^{\circ} \mathrm{C}$. the reversal appears twenty minutes after the beginning of the experiment.

Similar almost instantaneous effects of growth substances were demonstrated on the nyctinastic movements of various Oxalis spp., in which 2,4dichlorophenoxyacetic acid, 1-100 p.p.m., and also indolylacetic acid cause a suppression, or even reversal, of the normal movement of the leaflets. This effect, too, may be accounted for by a sudden change of turgor, in this case in the pulvinar cells.

With Bryophyllum and carrot tissue, preliminary experiments have shown that 2,4-dichlorophenoxyacetic acid (1-50 p.p.m.) does not increase permeability to neutral red or ammonium ions. Plasmolysis in hypertonic glucose, as well as in glycerol, is materially accelerated in 2,4-dichlorophenoxyacetic acid, even in concentrations as low as one part in ten million.

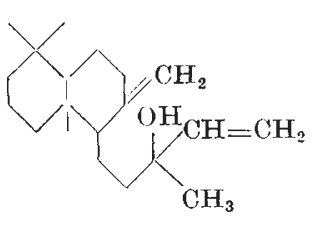

Mnaool
We have also observed the disappearance of air from the intercellularies after treatment with 2,4-dichlorophenoxyacetic acid. This phenomenon, caused by an extrusion of water or cell sap, had been observed already in 1930 by Miss Nicolai ${ }^{1}$ using cress roots mechanically stimulated at certain spots; at these spots the roots developed nodules. It is possible that the production of swellings by 2,4-dichlorophenoxyacetic acid, as well as the internal wilt which appears after its application, may yet be traced to the same cause, namely, an initial loss of water or sap from the cell.

The experimental work will be published in the near future. This research has been made possible by a grant from Timbrol Pty., Ltd., Australia.

L. G. M. BAas Becking

R. G. EvErSON

Department of Botany,

University of Sydney. April 24.

${ }^{1}$ Nicolai, E., D.Sc. thesis, Leyden (1930).

\section{Corchsularin, a New Bitter Principle from Jute Seeds (Corchorus capsularis, Linn.)}

SEN isolated corchorin ${ }^{1}$, a crystalline bitter principle of melting point $174^{\circ} \mathrm{C}$. and molecular composition $\mathrm{C}_{22} \mathrm{H}_{36} \mathrm{O}_{8}$ and corchoritin'2, having melting point 218--222 $2^{\circ}$. and molecular formula $\mathrm{C}_{12} \mathrm{H}_{18} \mathrm{O}_{3}$ from the alcoholic extract of jute seeds (Corchorus capsularis, Linn.). Karrer and Banerjee ${ }^{3}$ obtained corchortoxin, having melting point $247^{\circ} \mathrm{C}$. and molecular composition $\mathrm{C}_{23} \mathrm{H}_{32} \mathrm{O}_{6}$. Soliman and Saleh ${ }^{4}$ identified corchorin as strophanthjdin.

We are also engaged upon a study of the bitter principles of jute seeds. Simply by extracting jute seeds with rectified spirit and digesting the alcoholfree extract with boiling water, a better yield of corchorin has been obtained. Corchorin extracted in this manner agrees largely as regards properties with those described by Sen and fails to show its identity with strophanthidin. It has also been found that a new bitter accompanies corchorin. This has been isolated and crystallized. It has a melting point of $157^{\circ} \mathrm{C}$. and molecular composition $\mathrm{C}_{30} \mathrm{H}_{57} \mathrm{O}_{9}$. Since this is neither corchorin, corchoritin nor corchortoxin, we propose a new name, 'corchsularin', for the substance. Corchsularin yields, on acid-hydrolysis, a new deoxy sugar, for which we also propose the name 'corchsularose'. Corchsularose has been found to be a deoxy methyl pentose.

A fuller account of this work will be published elsewhere.

M. A. Khalique

M. AHMED

Organic Research Laboratory,

Department of Chemistry,

University of Dacca,

E. Pakistan

June 2.

${ }^{1}$ Sen, N. K., J. Ind Chem Soc., 7, 83, 905 (1930).

${ }^{2}$ Sen, N. K., J. Ind. Chem. Soc., 8, 651 (1931)

${ }^{3}$ Karrer, P., and Banerjee, P., Helv. Chim. Acta, 32, 2385 (1949).

4 Soliman, G., and Saleh, W., J. Chem. Soc., 1152 (1951). 